\title{
Možnosti divadelního textu
}

\author{
Michal Zahálka
}

Aleš Merenus, Iva Mikulová a Jitka Šotkovská (edd.). Text a divadlo. Praha: Academia, 2019. 411 s. ISBN 978-80-200-3108-2.

Čtenářům Theatralii jistě není třeba nijak zvlášt představovat aktivity Týmu pro výzkum moderního českého divadla, který v rámci Ústavu pro českou literaturu AV ČR vede Aleš Merenus - mimo jiné díky Supplementům 1/2017, 1/2018 a 1/2019, jež představily připravovaný slovník Moderni česká divadelni hra. Prvním knižním plodem práce týmu je poměrně obsáhlá kolektivní monografie Text a divadlo, kterou vedle Merenuse edičně připravily Iva Mikulová a Jitka Šotkovská. Vedle všech členů týmu do knihy přispěla i řada dalších českých i slovenských osobností z oborů, jež se různými způsoby dotýkají vztahů divadla a literatury, přičemž příspěvky se neomezují jen na ty čistokrevně literárněvědné a teatrologické. Gró knihy vychází ze stejnojmenného kolokvia, které tým uspořádal v červnu 2018, tedy hned v druhém roce své existence. Př́i pročítání jednotlivých studií je dobré mít toto východisko na paměti: zatímco velká část příspěvků tvoří opravdu nějaký vzájemně komplementární celek, který by bylo lze i z funkčního hlediska označit za kolektivní monografii, jsou tu i takové, které (jakkoliv samy o sobě třeba zajímavé a podnětné) tematicky přeci jen jaksi odstávají.

Nicméně popořádku. $\mathrm{V}$ mnoha ohledech dominantní součástí knihy je rozsáhlá studie Pavla Janouška „Divadlo a text jako průnik fuzzy množin“ s podtitulem „Úvaha nejen teoretická“. Autor v ní za pomoci řady zcela konkrétních postřehů z divadelních dějin i současnosti mapuje vývoj vnímání vztahů mezi divadlem a divadelním textem a z teoretického hlediska za pomoci konceptů jako drama, text pro divadlo a divadelni projekt ohledává různé možnosti, jak k tomuto vztahu přistoupit. Je to studie pojatá dosti zeširoka, nevěnuje se jen demonstraci jednoho konkrétního, úzce vymezeného teoretického př́stupu, ale otevírá celou řadu témat a možných úhlů pohledu. Do hry přitom vedle autorovy erudice vstupuje i jeho pověstný břitce ironický smysl pro humor. Díky tomu všemu mám dojem, že by si Janouškův bez malého mála stostránkový text býval zasloužil samostatné knižní vydání. Ba dokonce myslím, že se lze obejít i bez onoho minulého času: samostatné knižní vydání (s případným rozšířením a dopracováním) by si zasloužil i nyní, po mém soudu má totiž díky své myšlenkové otevřenosti a čtenářské př́stupnosti potenciál stát se i pro širší veřejnost či přinejmenším pro studenty souvisejících oborů jakýmsi uvedením $\mathrm{k}$ přemýšlení o současném divadle, dramatu a o tom, jak to mezi nimi je. Pokud by mé volání po samostatném vydání bylo náhodou vyslyšeno, vedle rozvedení některých myšlenek bych doporučil i poněkud systematiččější zdrojování některých anekdot z praxe použitých jako důkazní materiál. Konkrétně mě třeba zajímal zdroj k př́iběhu o tom, jak si anglická herečka 
Thorndiková (čímž se pravděpodobně myslí Sybil, byt’ v textu je skryta pod iniciály D.S. a v rejstříku dokonce po eliotovsku jako T.S., viz s. 66 a 410) vynutila změnu závěru Čapkovy Matky.

Zatímco Janouškův text stojí samostatně, zbytek knihy je rozčleněn do šestice tematických oddílů, přičemž příspěvky, jež v mých očích nejpodstatněji a nejkonkrétněji doplňují Janouškovy podněty, jsou rozesety $\mathrm{v}$ prvních pěti $\mathrm{z}$ nich. (Ten šestý oddíl, nazvaný Performeřri a pisničkárí, už názvem napovídá jistou cizorodost jakkoliv př́íspěvky Zuzany Spodniakové o Vladimíru Vysockém, Jakuba Kapičiaka o Dmitriji Prigovovi a Dáši Čiripové o performancích jistě stojí za pozornost.)

$\mathrm{V}$ oddílu nazvaném Teorie současného dramatu/divadelniho textu je tematicky dostředivou především stat Lenky Jungmannové „Zůstane drama divadlem?", jež si klade částečně tytéž otázky jako text Janouškův a ohledává povahu experimentálního dramatu ve vztahu k proměnám dalších literárních druhů. $\mathrm{V}$ závěru Jungmannová cituje německou teatroložku Gerdu Poschmannovou a její definici pojmu divadelni text. K Poschmannové se ve dvou následujících příspěvcích hojně odkazují Zuzana Augustová a Tereza Pavelková - obě blíže představují jednotlivé koncepty její teorie a obě je aplikují na různá díla Elfriede Jelinekové, přičemž Augustovou zajímají především pojetí intertextuality, kdežto Pavelkovou časoprostor. Tematicky zdánlivě poněkud exkluzivní, leč nesmírně podnětnou je stat’ versologa Roberta Kolára věnovaná úlohám verše v současném českém dramatu. Kolár v množství konkrétních analýz, v nichž se věnuje jak veršové formě, tak její funkci v daném díle, dokládá poměrně překvapivě širokou škálu užití vázané řeči - jakkoliv je zřejmé, že verš je v současném divadle čímsi vysoce příznakovým a rýmy jsou podle Kolára dokonce výhradně nositeli komiky.

V oddílu Poetiky - dramatické a režijni najdeme jenom dva př́spěvky. Aleš Merenus ve své metodologicko-teoretické úvaze zkoumá možnosti výzkumu historické poetiky českého dramatu - nedochází ke konkrétní aplikaci, ale nabízí určitá východiska vycházející z Veselovského, Genetta či Pfistera a naznačuje, jak by jimi byly obohaceny dosavadní české historické práce. Naproti tomu zcela konkrétně zacílený příspěvek Ivy Mikulové zkoumající používání pojmu režisérismus v těsně poválečné době je velice podnětnou studií doplňující téma proměn vztahu divadla $\mathrm{k}$ divadelnímu textu, jež je jedním z nejvýraznějších průběžných motivů celé knihy.

Název oddílu Dobové fenomény - publikováni a recepce díla je jaksi obecný, ale přesto úplně nepostihuje všechny obsažené studie. Konkrétně nevím, v jakém slova smyslu dobovým fenoménem je divadelní překlad, jemuž je věnován důkladný příspěvek Dimeho Mitrevského. Mitrevski podává systematický přehled dosavadního stavu translatologického bádání v tomto tématu, nastiňuje základní pojmy (přičemž snad poněkud překvapivě rozlišuje mezi pojmy adaptace a prepis; osobně jsem je vždy pokládal jako synonyma, což, pravda, Mitrevski rovněž jako možnost připouští) a naznačuje jejich aplikaci na příkladu nejrůznějších českých podob Gayovy, Brechtovy či Havlovy Žebrácké opery. Jana B. Wild se zaměřila na slovenskou shakespearovskou publikační tradici se zvláštním kritickým zřetelem k četným doprovodným komentár̆ům Aloise Bejblíka. Tematicky je i tento text $\mathrm{v}$ knize 
poněkud osamocený, ale čtení je to nesporně inspirativní (i jako pomyslný doplněk shakespearovské monografie Pavla Drábka) a díky autorčinu lehce jízlivému smyslu pro humor také výsostně zábavné. Oddíl uzavírá příspěvek Davida Kroči nazvaný „Knižní publikování dramatického textu jako znak literárnosti“ - titulek slibuje teoretický pohled na věc, ale Kroča se věnuje zejména mapování české praxe vydávání divadelních her v historii a především dnes. $\mathrm{V}$ historickém přehledu padnou i poněkud podezřele působící soudy, které by si zasloužily přinejmenším rozvinout a objasnit: „Ačkoli již na počátku 20. století se na dramatickou tvorbu zaměřilo několik našich nakladatelů [...], zvýšený zájem o promyšlené vydávání dramatických textů lze sledovat až pod vlivem ohrožení existence národní identity za Protektorátu Čechy a Morava“ (s. 249).

Na zmíněné téma intertextu navazuje blok Intertextové vztahy, který přináší dvojici slovenských příspěvků. Michaela Mojžišová zkoumá podoby operního libreta v novější tvorbě světové, ale především slovenské. Katarína Cupanová podává ve svém příspěvku analýzu dvou divadelních adaptací klasických děl slovenské literatury na scéně Slovenského národního divadla.

Téma obzvlášt inspirativního oddílu Dramatičti autoři pěkně vystihuje název první ze tří zahrnutých studií: „O tzv. nesmrtelnosti díla dramatického aneb Co zbylo z Hilberta“. Michal Fránek v ní nahlíží dílo Jaroslava Hilberta s vědomím historických souvislostí, ale zároveň optikou dnešního teoreticko-dramaturgického čtení s ohledem na tematickou stránku i formální výstavbu, díky čemuž velice konkrétně a věcně doplňuje ono zastřešující téma proměn úlohy textu v divadle v průběhu let. Podobně se Dagmar Kročanová vrací k dramatické tvorbě
Júlia Barče-Ivana (jakkoliv se její stat’ neobrací tak explicitně k dnešku), a Jitka Šotkovská zkoumá současné možnosti modelových her Václava Havla na základě jejich inscenací z posledních let.

Celkovému, jakkoliv vesměs pozitivnímu dojmu z celého svazku přeci jen trochu škodí jednak lehká tematická rozbíhavost, jednak fakt, že jednotlivé texty spolu příliš nekomunikují ani tam, kde by se to vysloveně nabízelo. Texty Zuzany Augustové a Terezy Pavelkové jsou nejenže velice podobně zaměřené, ale začínají co do obsahu prakticky totožnou první větou, takže informaci o zásadní monografii Gerdy Poschmannové čtenář získává postupně na stranách 137 (v závěru stati Lenky Jungmannové), 139 (Augustová) a 151 (Pavelková). Poněkud ukvapený Mitrevského soud, že „[z] faktu, že tento překlad nevyšel knižně, vyplývá, že byl určen pro konkrétní divadelní inscenaci konkrétního souboru s tím, že při jeho vzniku pravděpodobně nebylo počítáno s dalšími inscenacemi“ (s. 205), který příliš neodpovídá situaci na českém knižním trhu a trhu s divadelními překlady, by si býval zasloužil korekci s ohledem na téma studie Davida Kroči z téhož bloku. $\mathrm{V}$ těchto momentech kniha působí opravdu spíše dojmem konferenčního sborníku izolovaných textů než promyšleněji koncipované kolektivní monografie v pravém slova smyslu. Přesto ve výsledku tuto komplexnější funkci splňuje a přináší mnoho inspirativního, na co mohou další teatrologové a literární vědci v budoucnu navázat. Jakkoliv je těžké podávat o takto rozdílných studiích obecný soud, en bloc bych řekl, že se autorům vesměs daří teoretické koncepty a soudy podkládat konkrétními příklady, takže toho chvályhodně jen málo zůstává v abstraktní rovině. 
Velkým kladem knihy, jež vyšla péči dání tohoto svazku, ale vůbec celou aktivinakladatelství Academia, je také vysoká tu Týmu pro výzkum moderního českého úroveň zpracování co do redakce (překle- divadla, která je v široké škále úkolů obdipů či nedostatků v interpunkci jsem zazna- vuhodná. Jejich první kniha je, troufám si menal naprosté minimum), sazby (Pavel tvrdit, velkým př́íslibem.

Průša) i výroby. Vítat lze ovšem nejen vy- 